\title{
Davidian involucrata Leaves Extract as Green Corrosion Inhibitor for low carbon Steel in concrete pore solution containing chloride ions
}

\author{
Meng Zhang \\ Architectural Engineering Institute, Chong Qing Industry Polytechnic College, Chong Qing 401120, \\ China \\ E-mail:zhangmengcq2020@163.com
}

doi: $10.20964 / 2021.04 .01$

Received: 18 December 2020 / Accepted: 25 January 2021 / Published: 28 February 2021

In this work, we tried to use the Davidia involucrata leaves extract (DILE) as an eco-friendly inhibitor to enhance corrosion resistance of carbon steel plate in concrete pore solution containing chloride ions. The inhibiting performances of DILE were studied by electrochemical impedance spectroscopy and polarization analysis. Electrochemical results indicated that the DILE was an effective corrosion inhibitor in decreasing the corrosion behavior of carbon steel at the optimal dosage of $100 \mathrm{mg} / \mathrm{L}$ inhibitor. The potentiodynamic polarization results indicate that the DILE was a blended-type inhibitor that enhanced the performance of corrosion resistant in carbon steel plate considerably with formation of an organic layer to restrain both the anodic and the cathodic reactions. The surface morphology of a carbon steel plate immersed in concrete pore solution containing $100 \mathrm{mg} / \mathrm{L}$ DILE inhibitor revealed the formation of low corrosion products on steel which was in agreement with the results achieved from electrochemical assessments.

Keywords: Green inhibitor; Electrochemical corrosion; Carbon steel plate; Electrochemical impedance spectroscopy; Concrete pore solution

\section{$\underline{\text { FULL TEXT }}$}

(C) 2021 The Authors. Published by ESG (www.electrochemsci.org). This article is an open access article distributed under the terms and conditions of the Creative Commons Attribution license (http://creativecommons.org/licenses/by/4.0/). 